\title{
Formation of fibrillar structures through self-assembly of designed peptide turns
}

\author{
Sudeshna Kar, ${ }^{\mathrm{a}}$ Michael G. B. Drew, ${ }^{\mathrm{b}}$ and Animesh Pramanik ${ }^{\mathrm{a}, *}$ \\ ${ }^{a}$ Department of Chemistry, University of Calcutta, 92, A. P. C. Road, Kolkata-700 009, India \\ ${ }^{b}$ School of Chemistry, The University of Reading, Whiteknights, Reading RG6 6AD, UK \\ E-mail: animeshin2001@yahoo.co.in
}

\begin{abstract}
Three tripeptides Boc-Phe-Aib-Val-OMe (1), Boc-Leu-Aib- $p-\mathrm{NA}-\mathrm{NO}_{2}(2)$ and Boc-Pro-Aib- $m$ NA-NO $\mathrm{N}_{2}$ (3) (Aib: $\alpha$-aminoisobutyric acid; $p$ - and $m$-NA: para- and meta-nitroaniline) have been designed by incorporating aromatic rings to study the self-assembly and fibril formation. Single crystal X-ray diffraction studies show that all the peptides adopt turn-like structures that are selfassembled through intermolecular hydrogen bonds and van der Waals interactions to create layers of $\beta$-sheets. Solvent dependent NMR titration and CD studies show that the turn structures of the peptides also exist in the solution phase. The field emission scanning electron microscopic (FE-SEM) images of the peptides in the solid state reveal fibrillar structures of flat morphology that are formed through $\beta$-sheet mediated self-assembly of the preorganized turn building blocks.
\end{abstract}

Keywords: Peptides, turns, self-assembly, $\beta$-sheet, fibrils

\section{Introduction}

The design and synthesis of appropriate peptide subunits for desired supramolecular architecture is an important area of current research. Supramolecular helices ${ }^{1,2}$ and $\beta$-sheets ${ }^{3}$ are the most common supramolecular architectures derived from peptides through self-assembly. Supramolecular $\beta$-sheets have many potential applications in material ${ }^{4-7}$ as well as in biological sciences. ${ }^{8-11}$ Amyloid fibril forming $\beta$-sheets are the causative factors of many neurodegenerative diseases. ${ }^{12,13}$ It has been observed that a $\beta$-turn subunit can either form a supramolecular $\beta$-sheet or a supramolecular helix through self-assembly. ${ }^{14-17}$ In this paper we are interested in designing small synthetic peptides that exhibit turn structures, and have the potential to form supramolecular $\beta$-sheets through molecular self-assembly. 
<smiles>COC(=O)C(NC(=O)C(C)(C)NC(=O)C(Cc1ccccc1)NC(=O)OC(C)(C)C)C(C)C</smiles>

Peptide 1<smiles>CC(C)CC(NC(=O)OC(C)(C)C)C(=O)NC(C)(C)C(=O)Nc1ccc([N+](=O)[O-])cc1</smiles>

Peptide 2<smiles>CC(C)(C)OC(=O)N1CCCC1C(=O)NC(C)(C)C(=O)Nc1cccc([N+](=O)[O-])c1</smiles>

Peptide 3

Figure 1. Schematic representation of peptides 1-3.

Three model tripeptides Boc-Phe-Aib-Val-OMe (1), Boc-Leu-Aib- $p-\mathrm{NA}-\mathrm{NO}_{2}(2)$ and BocPro-Aib- $m$-NA- $\mathrm{NO}_{2}$ (3) (Aib: $\alpha$-aminoisobutyric acid; $p$ - and $m$-NA: para- and metanitroaniline) with a centrally placed non-coded amino acid Aib have been chosen to study the self-assembly and fibril formation (Fig. 1). Since it is well established that short aromatic peptides have the ability to form $\beta$-sheet mediated amyloid fibrils, ${ }^{18}$ peptides $\mathbf{1 - 3}$ have been designed incorporating aromatic rings. While peptide $\mathbf{1}$ contains an aromatic ring in the side chain, peptide $\mathbf{2}$ and $\mathbf{3}$ incorporate aromatic rings in the backbone. Generally conformationally restricted Aib is a $\beta$-sheet breaker and highly helicogenic. ${ }^{19}$ Therefore peptides 1-3 with a centrally positioned $\mathrm{Aib}(2)$ are expected to adopt turn-like structures. ${ }^{20-22}$ It will be interesting to know whether the incorporation of $p$ - and $m$-nitroanilnes in peptide $\mathbf{2}$ and $\mathbf{3}$ assists or disrupts the 
creation of turn structures. There are examples of constrained cyclic peptides in which substituted benzenes have been inserted to mimic the turn region of the neurotrophin, a nerve growth factor. ${ }^{23}$ Peptide $\mathbf{2}$ and $\mathbf{3}$ will be examples of acyclic analogues if they adopt turn-like structures. The present study will also reveal the influence of aromatic rings in self-assembly, specially in the formation of supramolecular $\beta$-sheets and fibrillar structures. Peptides 1-3 were synthesized using conventional solution phase methodology and their solid-state structures and crystal packing were determined by X-ray diffraction analyses. The peptide conformations in the solution phase were probed by $\mathrm{CD}$ and NMR studies. Field emission scanning electron microscopy (FE-SEM) has been employed to investigate the morphological properties of the peptides in the solid state.

\section{Results and Discussion}

\section{Crystal structures of peptides}

Peptide 1 crystallizes in spacegroup $\mathrm{P} 22_{1}$ with two molecules $\mathbf{1 A}$ and $\mathbf{1 B}$ in the crystallographic asymmetric unit. The structure of the two molecules is shown in Figure 2 and it is apparent that the two molecules for the most part conform to centrosymmetric pairs, indeed the majority of the coordinates fit to spacegroup $\mathrm{P} 2{ }_{1} / \mathrm{c}$. The chirality at $\mathrm{C}(4 \mathrm{~A})$ is $R$ and at $\mathrm{C}(4 \mathrm{~B})$ is $S$ but the symmetry is broken by $\mathrm{C}(10 \mathrm{~A})$ and $\mathrm{C}(10 \mathrm{~B})$ which both have chirality $S$ which conformed with the starting material. During the synthesis it is clear that epimerization has occurred at Phe of molecule 1A to produce molecule 1B with opposite chirality at C(4). However the main conformational features of the two molecules are similar. Thus $\mathbf{1 A}$ reveals a type II' $\beta$-turn-like structure with Phe(1) and Aib(2) occupying the $i+1$ and $i+2$ positions respectively (Fig. 2). The torsion angles at Phe(1) and Aib(2) were found to $\varphi_{1}: 66.8(2), \psi_{1}:-146.3(2)^{\circ}$ and $\varphi_{2}:$ $60.0(2), \psi_{2}:-37.6(2)^{\circ}$, respectively (Table 1 ), which deviate significantly from the ideal values for a type II' $\beta$-turn $\varphi_{1}: 60, \psi_{1}:-120$ and $\varphi_{2}:-80, \psi_{2}: 0 .{ }^{24}$ The molecule $\mathbf{1 B}$, where the Phe has $S$ chirality, adopts a type II $\beta$-turn-like structure, diastereomeric to $\mathbf{1 A}$, with Phe(1) and Aib(2) as corner residues (Fig. 2 and Table 1). The torsion angles at Phe(1) and Aib(2) were found to $\varphi_{1}$ : 61.3(2), $\psi_{1}: 144.7(2)^{\circ}$ and $\varphi_{2}: 54.6(2), \psi_{2}: 37.8(2)^{\circ}$, respectively. In 1B, the observed $\mathrm{N}(3 \mathrm{~B}) \ldots \mathrm{O}(9 \mathrm{~B})$ distance between the Boc-CO and Val(3)-NH groups is far too long at 3.61(1) $\AA$ for an intramolecular $4 \rightarrow 1$ hydrogen bond. Importantly such turn-like structures, which do not contain intramolecular hydrogen bonds are solely stabilized by co-operative steric interactions amongst the amino acids residues and are generally referred to as open turns. ${ }^{25}$ 


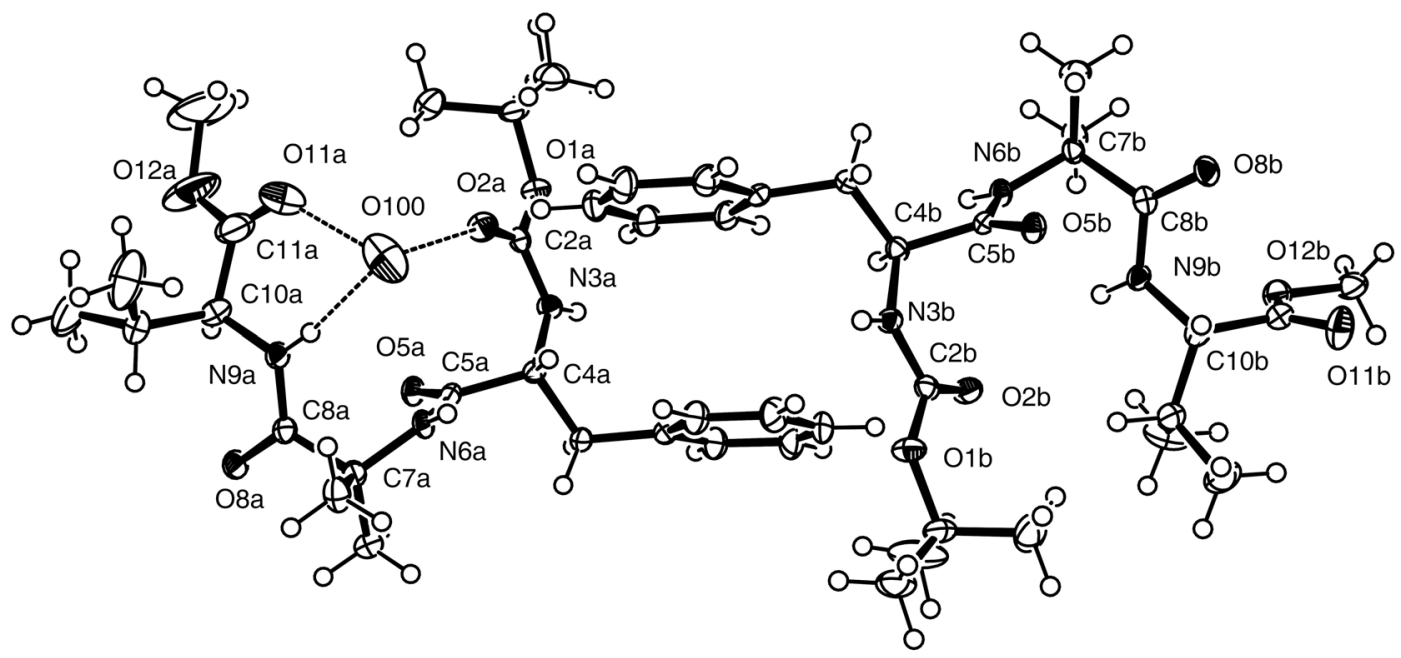

1A

1B

Figure 2. ORTEP diagram of peptide 1 (A \& B) with atom numbering scheme showing the pseudo centre of symmetry broken at $\mathrm{C}(10)$. Ellipsoids at $50 \%$ probability. Hydrogen bonds are shown as dotted lines.

Table 1. Selected back-bone torsion angles $\left({ }^{\circ}\right)$ for the peptides 1-3

\begin{tabular}{ccccc}
\hline Peptide & Residue & $\phi$ & $\psi$ & $\omega$ \\
\hline 1A & Phe(1) & $66.8(2)$ & $-146.3(2)$ & $-158.9(2)$ \\
& Aib(2) & $-60.0(2)$ & $-37.6(2)$ & $177.2(2)$ \\
& Val(3) & $-158.9(2)$ & $162.8(2)$ & \\
1B & Phe(1) & $-61.3(2)$ & $144.7(2)$ & $167.5(2)$ \\
& Aib(2) & $54.6(2)$ & $37.8(2)$ & $-168.5(2)$ \\
& Val(3) & $-63.1(2)$ & $-37.8(2)$ & \\
\multirow{2}{*}{3} & Leu(1) & $-62.9(4)$ & $143.1(3)$ & $168.7(3)$ \\
& Aib(2) & $63.5(4)$ & $23.4(4)$ & $179.0(4)$ \\
& Pro(1) & $-48.2(3)$ & $133.5(2)$ & $173.1(2)$ \\
& Aib(2) & $66.1(3)$ & $18.6(3)$ & $168.6(2)$ \\
\hline
\end{tabular}

However in 1A, a water molecule, $\mathrm{O}(100)$ is found within the cavity formed by the turn structure, albeit with $50 \%$ probability, and this solvent molecule forms three hydrogen bonds, as

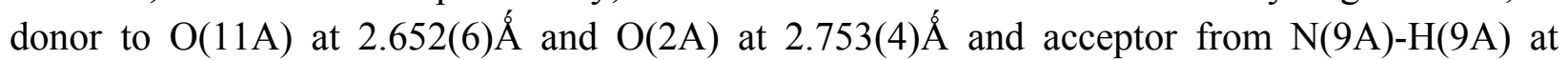
$3.039(5) \AA$. As a consequence the $\mathrm{N}(3 \mathrm{~A})$...O $(9 \mathrm{~A})$ distance is extended even longer than the $\mathrm{N}(3 \mathrm{~B}) . . . \mathrm{O}(9 \mathrm{~B})$ distance at 4.22(1) ̊́. There are additional intermolecular hydrogen bonds involving $\mathrm{N}(3)-\mathrm{H}$ and $\mathrm{N}(6)-\mathrm{H}$ in both molecules with carbonyls $\mathrm{O}(5)$ and $\mathrm{O}(8)$ (Table 2). On the other hand $\mathrm{N}(9 \mathrm{~A})-\mathrm{H}$ only forms a hydrogen bond with the solvent $\mathrm{O}(100)$, while $\mathrm{N}(9 \mathrm{~B})-\mathrm{H}$ is unattached. 
Peptide 2 crystallizes in the centrosymmetric spacegroup $\mathrm{Pbcn}$ thus contains the two diastereomers with type II and II' $\beta$-turn-like conformations, with Leu(1) and Aib(2) as corner residues (Fig. 3, Table 1). The torsion angles at $\operatorname{Leu}(1)$ and $\operatorname{Aib}(2)$ were found to $\varphi_{1}:-62.9(4), \psi_{1}$ $: 143.1(2)^{\circ}$ and $\varphi_{2}: 63.5(4), \psi_{2}: 23.4(4)^{\circ}$ respectively, similar to those in peptide $\mathbf{1}$. As in $\mathbf{1 A}$ and 1B, the conformation does not allow for a strong intramolecular $4 \rightarrow 1$ hydrogen bond between $p$ NA-NH and Boc-CO with N(9)...O(2) 3.66(1) ̊̊ (Table 2). However as in 1, N(3)-H(3) forms a hydrogen bond with $\mathrm{O}(5)(1-\mathrm{x}, 1-\mathrm{y},-\mathrm{z})$ at $2.912(3) \AA$ and $\mathrm{N}(6)-\mathrm{H}(6)$ with $\mathrm{O}(8)(1.5-\mathrm{x}, 0.5+\mathrm{y}, \mathrm{z})$ at 2.934(3)Á while N(9)-H(9) remains unattached unless the weak intramolecular interaction with $\mathrm{O}(2)$ is considered.

The crystal structure of the peptide Boc-Pro-Aib- $m-\mathrm{NA}-\mathrm{NO}_{2}(3)$ is determined in the noncentrosymmetric spacegroup $\mathrm{P} 2{ }_{1} 2_{1} 2$. While the chirality was not determined from the crystal structure determination, the enantiomer with $\mathrm{C}(4)$ having the $S$ chirality was selected to conform with the reactant. The structure reveals a turn-like structure similar to that found in peptide $\mathbf{1}$ and 2 with Pro(1) and Aib(2) occupying the $i+1$ and $i+2$ positions respectively (Fig. 4). The torsion angles at the corner residues $\operatorname{Pro}(1)$ and $\operatorname{Aib}(2)$ are found to be as $\varphi_{1}:-48.2(3)^{\circ}, \psi_{1}: 133.5(2)^{\circ}$ and $\varphi_{2}: 66.1(3)^{\circ}, \psi_{2}: 18.6(3)^{\circ}$, respectively, indicating a type II $\beta$-turn structure (Table 1$)$. The turn structure is stabilized by a $4 \rightarrow 1$ hydrogen bond between $m$-NA-NH and Boc-CO with the N9...O2 distance at 3.075(2) $\AA$, very much shorter than the equivalent distance in $\mathbf{1}$ and $\mathbf{2}$ (Table 2).

Table 2. Hydrogen bonds parameters for peptides 1-3

\begin{tabular}{lccc}
\hline Type & $\mathrm{N} \ldots . . \mathrm{O} /(\AA)$ & $\mathrm{H} \ldots . . \mathrm{O} /(\AA)$ & $\mathrm{O} \ldots . \mathrm{H}-\mathrm{N} /\left(^{\circ}\right)$ \\
\hline Peptide 1A & & & \\
$\mathrm{N} 3(\mathrm{~A})-\mathrm{H} 3(\mathrm{~A}) \ldots . \mathrm{O}(5 \mathrm{~B})^{a}$ & $2.905(2)$ & 2.08 & 160 \\
$\mathrm{~N}(6 \mathrm{~A})-\mathrm{H}(6 \mathrm{~A}) \ldots \mathrm{O}(8 \mathrm{~A})^{b}$ & $2.849(2)$ & 2.26 & 125 \\
$\mathrm{~N} 9(\mathrm{~A})-\mathrm{H} 9(\mathrm{~A}) \ldots . \mathrm{O}(100)$ & $3.039(5)$ & 2.19 & 172 \\
$\mathrm{O}(100)^{*} \ldots \mathrm{O}(2 \mathrm{~A})$ & $2.753(4)$ & & \\
$\mathrm{O}(100)^{*} \ldots \mathrm{O}(11 \mathrm{~A})$ & $2.652(6)$ & & \\
Peptide 1B & & & \\
$\mathrm{N}(3 \mathrm{~B})-\mathrm{H}(3 \mathrm{~B}) \ldots \mathrm{O}(5 \mathrm{~A})^{c}$ & $2.948(2)$ & 2.08 & 156 \\
$\mathrm{~N}(6 \mathrm{~B})-\mathrm{H}(6 \mathrm{~B}) \ldots \mathrm{O}(8 \mathrm{~B})^{d}$ & $2.937(2)$ & 2.26 & 135 \\
Peptide 2 & & & \\
$\mathrm{N}(3)-\mathrm{H}(3) \ldots \mathrm{O}(5)^{e}$ & $2.912(3)$ & 2.09 & 160 \\
$\mathrm{~N}(6)-\mathrm{H}(6) \ldots . \mathrm{O}(8)^{f}$ & $2.934(3)$ & 2.07 & 166 \\
Peptide 3 & & & \\
Intramolecular & & & \\
$\mathrm{N}(9)-\mathrm{H}(9) \ldots \mathrm{O}(2)$ & $3.075(2)$ & 2.29 & 151 \\
Intermolecular & & & \\
$\mathrm{N}(6)-\mathrm{H}(6) \ldots . . \mathrm{O}(8)^{g}$ & $2.930(2)$ & 2.08 & 172 \\
\hline
\end{tabular}

Symmetry elements: ${ }^{a} \mathrm{x}, 1+\mathrm{y}, \mathrm{z} ;{ }^{b} 1-\mathrm{x}, \mathrm{y}-0.5,2-\mathrm{z} ;{ }^{c} \mathrm{x}, \mathrm{y}-1, \mathrm{z} ;{ }^{d} 1-\mathrm{x}, \mathrm{y}+0.5,1-\mathrm{z} ;{ }^{e} 1-\mathrm{x}, 1-\mathrm{y},-\mathrm{z} ;{ }^{f} 1.5-\mathrm{x}$, $0.5+\mathrm{y}, \mathrm{z} ;{ }^{\mathrm{g}} \mathrm{x}, \mathrm{y}, 1+\mathrm{z}$.

* Hydrogen atoms on the water molecule $\mathrm{O}(100)$ were not located. 


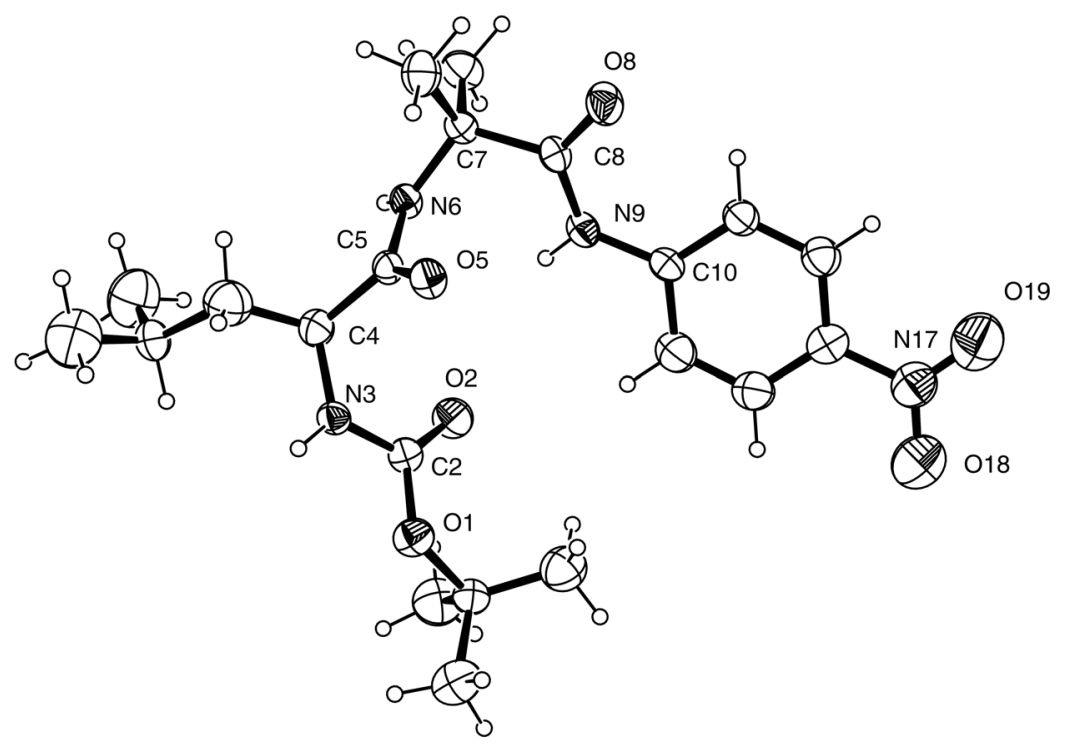

Figure 3. ORTEP diagram of peptide 2 with atom numbering scheme. Ellipsoids at 50\% probability.

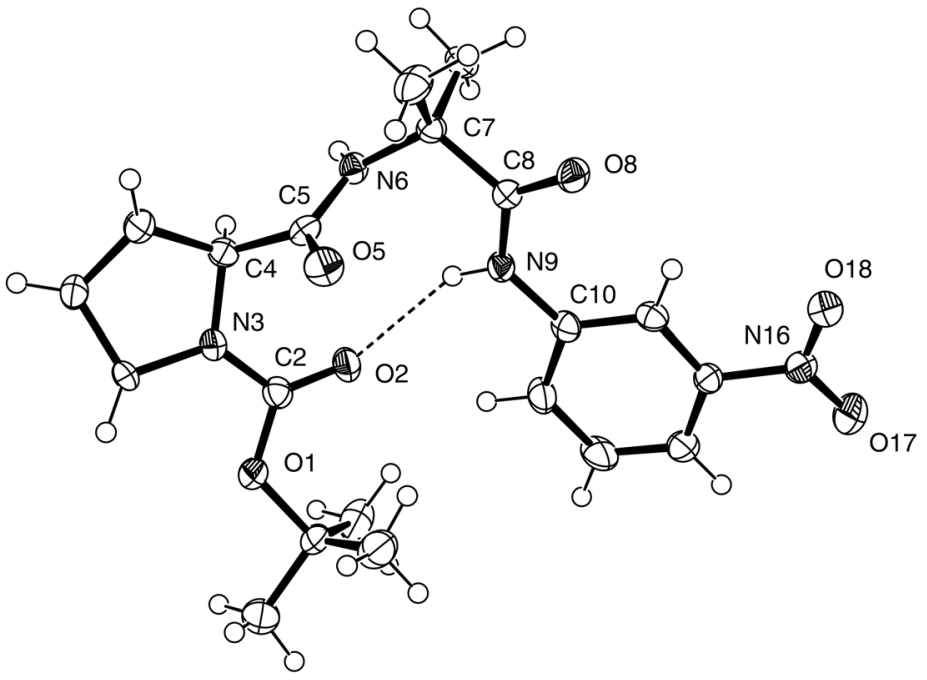

Figure 4. ORTEP diagram of peptide 3 with atom numbering scheme. Ellipsoids at 50\% probability. Hydrogen bond as dotted line.

\section{Crystal packing of peptides}

Crystal structure analysis shows that the turn structures of peptides $\mathbf{1}$ and $\mathbf{2}$ are packed in a similar fashion to form layers of $\beta$-sheets (Fig. 5 and 6). In each case six peptide molecules are interconnected by two types of intermolecular hydrogen bonds $\mathrm{Xx}(1)-\mathrm{CO} \ldots \mathrm{NH}-\mathrm{Xx}(1)$ and Aib(2)-CO...NH-Aib(2) to complete each circular subunit (Fig. 5a \& 6a, Table 2). These circular 
subunits are interconnected to create layers of $\beta$-sheets such as $a c$ plane for peptide $\mathbf{1}$ and $b c$ plane for peptide 2. The layer structures of the peptides are further self-assembled along the crystallographic directions $b$ (for $\mathbf{1}$ ) and $a$ (for 2) via van der Waals interactions to form higher order supramolecular $\beta$-sheet structures (Fig. $5 b \quad \& 6 b$ ). In the case of peptide 3 , the intermolecular hydrogen bond $\mathrm{Xx}(1)-\mathrm{CO} \ldots \mathrm{NH}-\mathrm{Xx}(1)$ does not exist as the Pro(1) residue does not provide a suitable proton. The only hydrogen bond Aib(2)-CO...NH-Aib(2) connects the molecules of $\mathbf{3}$ in the $b$ direction to form semicylindrical structures, which are packed through van der Waals interactions to create layers of $\beta$-turns in the $a c$ plane (Fig. 7). Therefore all the peptides 1-3 create $\beta$-sheet-like structure through molecular self-assembly, consistent with the previous results. ${ }^{17}$
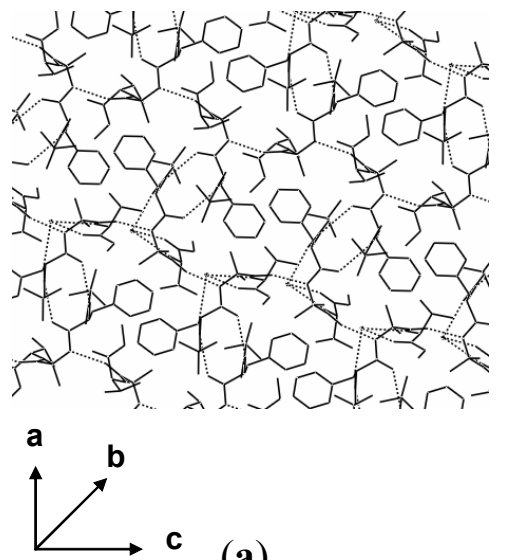
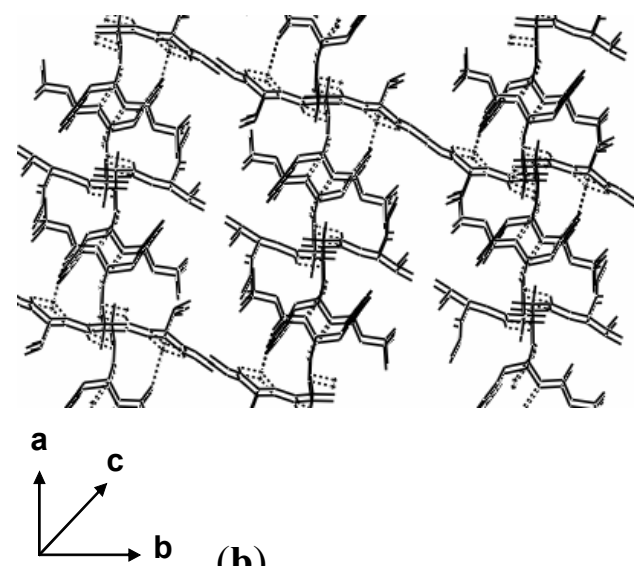

(b)

Figure 5. Packing pattern of peptide 1 showing (a) the formation of $\beta$-sheet layer in the $a c$ plane. Only intermolecular hydrogen bonds are shown with dotted lines; (b) the formation of supramolecular $\beta$-sheet through the higher order self-assembly of layers in the $b$ direction.

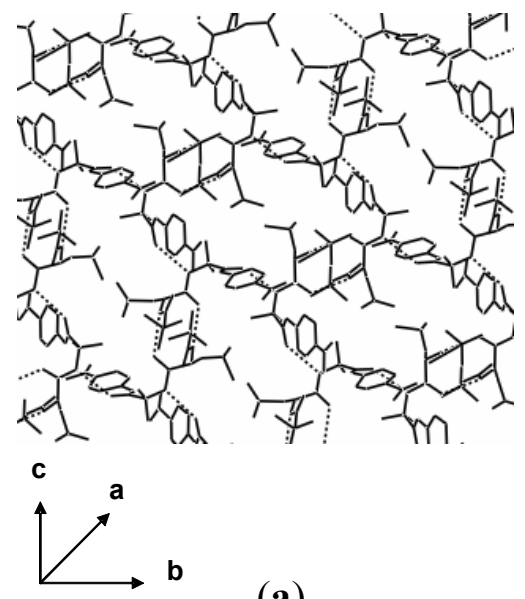

(a)

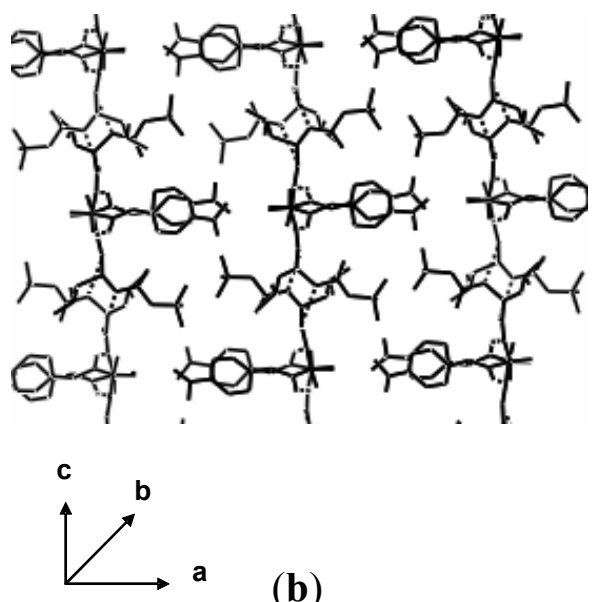

(b)

Figure 6. Packing pattern of peptide 2 showing (a) the formation of $\beta$-sheet layer in $b c$ plane. Only intermolecular hydrogen bonds are shown with dotted lines; (b) the formation of supramolecular $\beta$-sheet through the higher order self-assembly of layers in $a$ direction. 


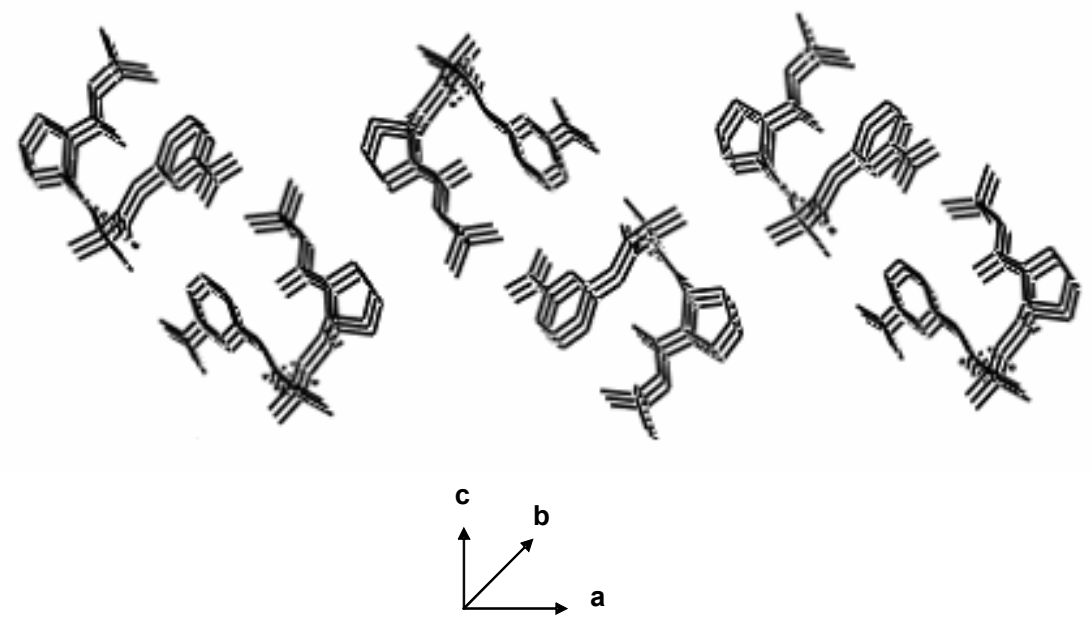

Figure 7. Packing pattern of peptide 3 showing the formation of semicylindrical structures in the $b$ direction. The cylindrical structures are packed through van der Waals interactions to form layers of $\beta$-turns in the $a c$ plane.

\section{Peptide conformations in solution}

The solution phase conformation of the peptide 1 was probed by NMR solvent titration method. In this experiment a solution of the peptide 1 in nonpolar $\mathrm{CDCl}_{3}(10 \mathrm{mM}$ in $0.5 \mathrm{ml})$ was gradually titrated against polar $\left(\mathrm{CD}_{3}\right)_{2} \mathrm{SO}$ and the changes in the chemical shifts of NHs were recorded by ${ }^{1} \mathrm{H}$ NMR (Fig. 8). ${ }^{26}$ The solvent titration shows that by increasing the percentage of $\left(\mathrm{CD}_{3}\right)_{2} \mathrm{SO}$ in $\mathrm{CDCl}_{3}$ from 0 to $10 \%$ the net changes in the chemical shift $(\Delta \delta)$ values for Phe(1)$\mathrm{NH}, \mathrm{Aib}(2)-\mathrm{NH}$ and $\mathrm{Val}(3)-\mathrm{NH}$ are $0.94,0.84$ and $0.10 \mathrm{ppm}$, respectively. The $\Delta \delta$ values demonstrate that $\mathrm{Val}(3)-\mathrm{NH}$ is solvent shielded, and the other two $\mathrm{NH}$ groups are solvent exposed, which is a characteristic feature of a turn-like structure where the $\mathrm{Val}(3)-\mathrm{NH}$ is involved in an intramolecular hydrogen bond to Boc-CO. Although peptide 1A and 1B do not form any intramolecular hydrogen bond in crystal structure (Fig. 2), in the solution phase they build up intramolecular $4 \rightarrow 1$ hydrogen bond. The $\mathrm{CD}$ spectrum of peptide 1 at $25^{\circ} \mathrm{C}$ in methanol reveals a positive ellipticity in the far-UV region with distinct double maxima at 206 and $222 \mathrm{~nm}$, suggesting the presence of a turn structure (Fig. 9). ${ }^{27}$

In ${ }^{1} \mathrm{H}$ NMR solvent titration of peptide 2 the net change in the chemical shift $(\Delta \delta)$ values for Leu(1)-NH, Aib(2)-NH and $p-\mathrm{NA}(3)-\mathrm{NH}$ are 1.03, 0.93 and 0.00 ppm, respectively (Fig. 10), indicating a turn-like structure where $p-\mathrm{NA}(3)-\mathrm{NH}$ is hydrogen bonded to Boc-CO. Interestingly the crystal structure of 2 does not contain any intramolecular $4 \rightarrow 1$ hydrogen bond (Fig. 4). The CD spectra of peptide $\mathbf{2}$ in methanol displays a strong positive ellipticity in the far-UV region with a distinct maxima at $199 \mathrm{~nm}$ (Fig. 9), which indicates the presence of a turn structure.

The solvent dependence of the $\mathrm{NH}$ chemical shifts, that is demonstrated in this $\mathrm{CDCl}_{3}-\left(\mathrm{CD}_{3}\right)_{2} \mathrm{SO}$ titration experiment, indicates that Aib(2)-NH is free and $m-\mathrm{NA}(3)-\mathrm{NH}$ is hydrogen bonded in peptide 3 with $\Delta \delta$ values as 0.97 and -0.06 ppm respectively, indicating a $\beta$-turn structure (Fig. 
11). A positive ellipticity with a maxima at $197 \mathrm{~nm}$ is observed in the CD spectra of 3 in methanol (Fig. 9), indicating the population of $\beta$-turn structure. Therefore, the results of solvent dependent NMR titrations and CD spectroscopy strongly favor the conclusion that the peptides 1-3 are folded into turn structures in the solution phase.

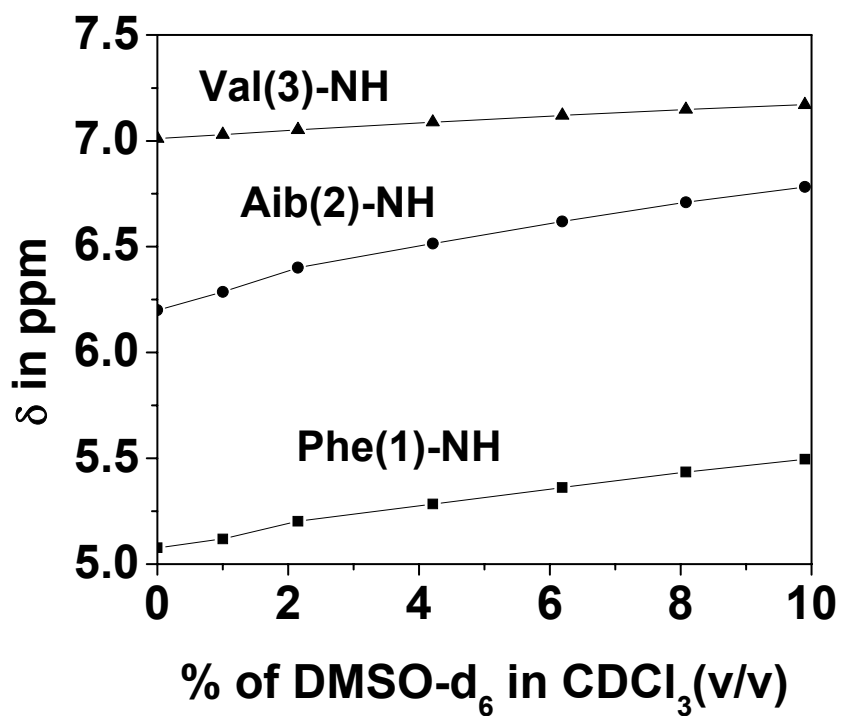

Figure 8. NMR solvent titration curve for NH protons in peptide 1.

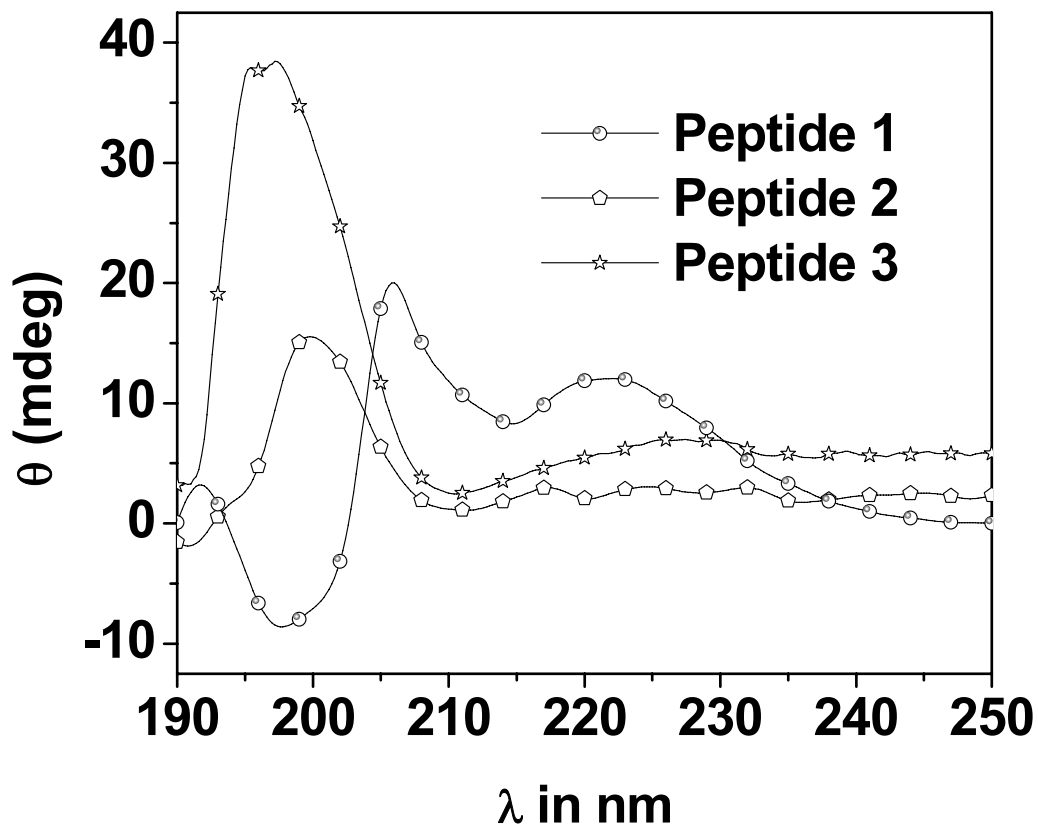

Figure 9. CD curves of peptides $\mathbf{1 - 3}$ in methanol $(1.5 \mathrm{mM})$. 


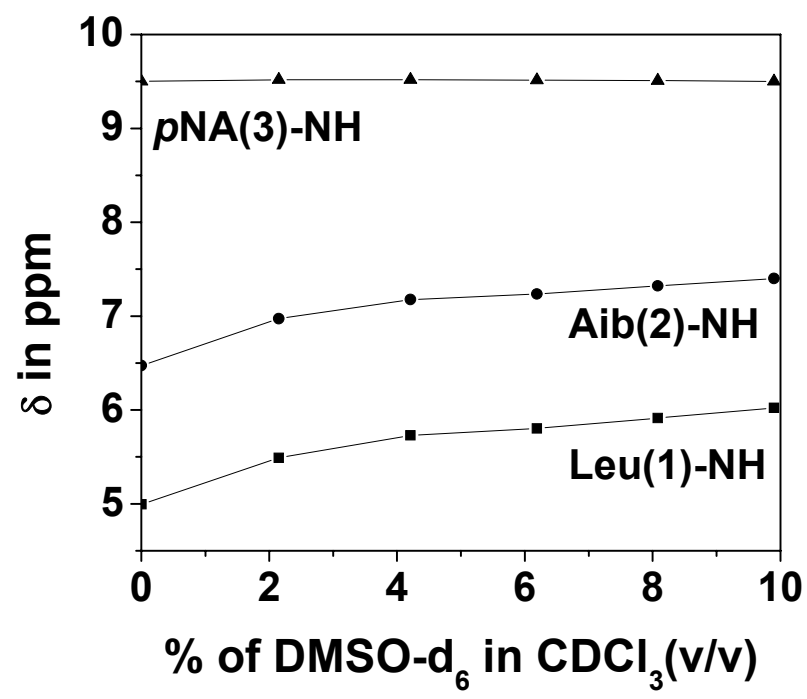

Figure 10. NMR solvent titration curve for NH protons in peptide 2.

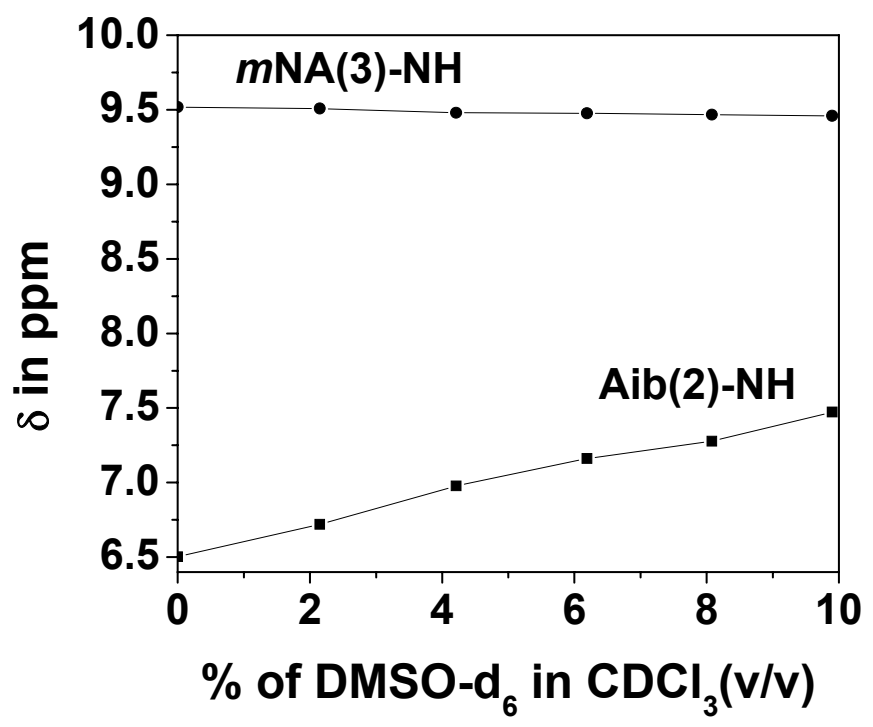

Figure 11. NMR solvent titration curve for NH protons in peptide 3.

\section{Morphological studies}

In addition to naturally occurring amyloid proteins, researchers have studied a variety of other $\beta$ sheet fibril-forming motifs derived from amyloid protein fragments, de novo designed peptides, peptidomimetics, and peptide amphiphiles. Schneider et al have reported the formation of flat fibril laminates through $\beta$-sheet mediated self-assembly of peptide with central Pro-Pro fragment. ${ }^{28}$ The quasi-crystalline structures of flat and non-twisted morphology are useful for specific nano-applications. Various attempts to fabricate these types of structures using amyloid 
proteins, peptides, and viruses have been reported. ${ }^{29}$ Therefore we became interested in exploring the possibility of fibril formation in peptides 1-3. Field emission scanning electron microscopic (FE-SEM) images of the dried fibrous material of peptides 1-3 grown slowly from ethylacetate-petroleum ether (for $\mathbf{1}$ ) and acetone (for $\mathbf{2} \& 3$ ) clearly demonstrate that the aggregates in the solid state are bunches of fibrillar structures of flat morphology (Fig. 12a-c). The fibrillar structures are formed through $\beta$-sheet mediated self-assembly of the preorganized turn-like building blocks.

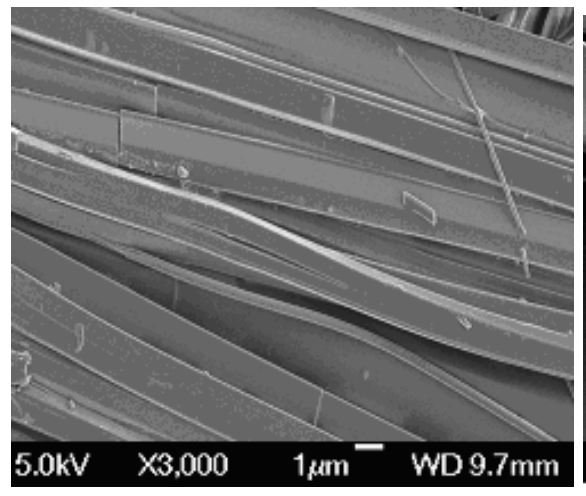

(a)

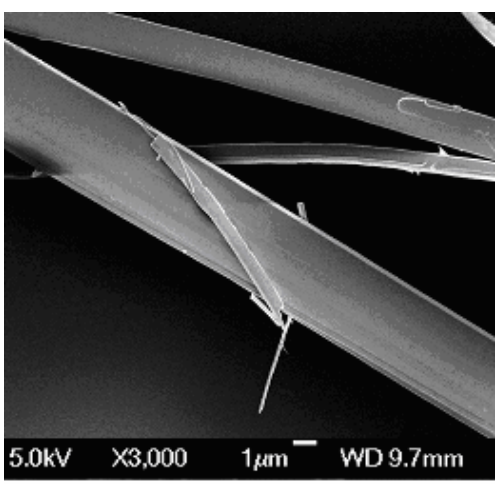

(b)

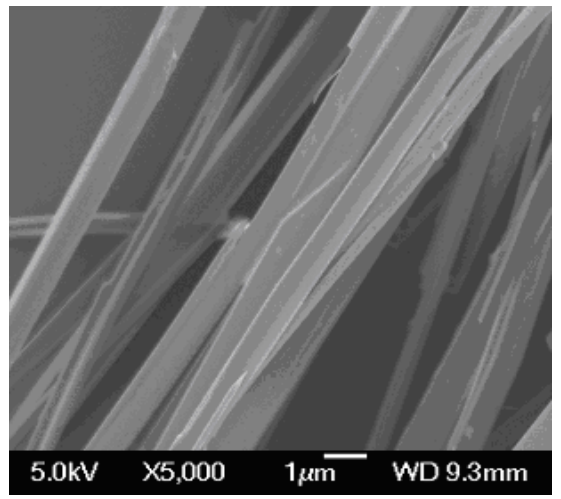

(c)

Figure 12. FE-SEM images of (a) peptide 1, (b) peptide 2 and (c) peptide 3 showing the formation of fibrillar structures of flat morphology in the solid state. The fibrous materials of peptide $\mathbf{1}$ was grown slowly from ethylacetate-petroleum ether and peptide $\mathbf{2}$ and $\mathbf{3}$ from acetone. They were dried and gold coated.

\section{Conclusions}

The present studies show that the turn-like structures of peptides 1-3 are quite stable and exist both in the solid state and in solution. Due to the presence of flat aromatic rings in the backbones these turn structures show a high tendency to form supramolecular $\beta$-sheets through molecular self-assembly. It has been shown that these preorganized turn building blocks generate flat fibrillar structures through $\beta$-sheet mediated self-assembly. The importance of $\pi$ - $\pi$ interactions in 
the formation of amyloid fibrils has been documented previously. ${ }^{30}$ The present study provides useful insights about the design and self-assembly of peptides, specifically, the relationship between peptide structure and the consequent morphology of the self-assembled materials.

\section{Experimental Section}

\section{Synthesis of the peptides}

The peptides were synthesized by conventional solution phase methods. The t-butyloxycarbonyl (Boc) group was used for N-terminal protection and the C-terminus was protected as the methyl ester. Couplings were mediated by dicyclohexylcarbodiimide (DCC)/ 1-hydroxybenzotriazol (HOBT). All intermediates were characterized by thin layer chromatography on silica gel and used without further purification. Final peptides were purified by column chromatography using silica gel (100-200 mesh) as the stationary phase. Ethylacetate and petroleum ether mixture was used as the eluent. The reported peptides 1-3 were fully characterized by X-ray crystallography and NMR studies.

\section{Synthesis of the peptide 1, Boc-Phe-Aib-Val-OMe}

Peptide Boc-Phe-Aib-OH ${ }^{22(e)}(2.30 \mathrm{~g}, 6.60 \mathrm{mmol})$ was dissolved in dimethylformamide (DMF, $10 \mathrm{ml})$. Val-OMe obtained from its hydrochloride $(2.20 \mathrm{~g}, 13.00 \mathrm{mmol})$ was added to the former solution in ice-cold condition followed by addition of DCC $(2.00 \mathrm{~g}, 9.70 \mathrm{mmol})$. The reaction mixture was stirred at room temp. for 2 days. The precipitated dicyclohexylurea (DCU) was filtered off. The filtrate was diluted with ethylacetate. The organic layer was washed with $1 \mathrm{~N}$ $\mathrm{HCl}(3 \times 30 \mathrm{ml})$, brine, $1 \mathrm{M} \mathrm{Na}_{2} \mathrm{CO}_{3}$ solution $(3 \times 30 \mathrm{ml})$ and again with brine. The solvent was then dried over anhydrous $\mathrm{Na}_{2} \mathrm{SO}_{4}$ and evaporated in vacuo giving a light yellow gum. Yield: $2.50 \mathrm{~g}(82.20 \%)$. Single crystals were grown from ethylacetate-petroleum ether solvent by slow evaporation and were stable at room temp. $\mathrm{Mp}=94^{0} \mathrm{C}$. Anal.Calcd for $\mathrm{C}_{24} \mathrm{H}_{37} \mathrm{~N}_{3} \mathrm{O}_{6}$ (463.55): $\mathrm{C}$, 62.17; H, 8.04; N, 9.06. Found: C, 62.22; H, 8.09; N, 9.11\%. [ $\alpha]_{589}^{20}=-28^{0}$ (c $=0.10$ g per 100 ml; $\left.\mathrm{CH}_{3} \mathrm{OH}\right)$; IR (KBr): 3330, 3305, 2972, 1704, 1662, $1532 \mathrm{~cm}^{-1} ;{ }^{1} \mathrm{H}$ NMR $300 \mathrm{MHz}\left(\mathrm{CDCl}_{3}\right.$, $\delta$ ppm): 7.25-7.34 (Phenyl ring protons), 7.01 (Val-NH, 1H, d), 6.20 (Aib -NH, s), 5.07 (Phe$\mathrm{NH}, 1 \mathrm{H}, s), 4.45-4.50\left(\mathrm{C}^{\alpha} \mathrm{H}\right.$ of Val, $\left.1 \mathrm{H}, m\right), 4.24\left(\mathrm{C}^{\alpha} \mathrm{H}\right.$ of Phe, $\left.2 \mathrm{H}, m\right), 3.72\left(-\mathrm{OCH}_{3}, 3 \mathrm{H}, s\right), 3.04$ $-3.08\left(\mathrm{C}^{\beta} \mathrm{H}\right.$ of Phe, $\left.2 \mathrm{H}, m\right), 2.16-2.18\left(\mathrm{C}^{\beta} \mathrm{H}\right.$ of Val, $\left.1 \mathrm{H}, m\right), 1.61\left(\mathrm{Boc}_{-} \mathrm{CH}_{3} \mathrm{~s}, 9 \mathrm{H}, s\right), 1.45$ and $1.50\left(\mathrm{C}^{\beta} \mathrm{H}\right.$ of Aib, 6H, s), 0.89-0.97 $\left(\mathrm{C}^{\gamma} \mathrm{H}\right.$ of Val, $\left.6 \mathrm{H}, m\right)$; HR-MS $\left(\mathrm{M}^{+} \mathrm{Na}^{+}\right)=485.975, \mathrm{M}_{\text {calcd }}$ $\left(\mathrm{M}^{+} \mathrm{Na}\right)^{+}=486.55$.

\section{Synthesis of the peptide 2, Boc-Leu-Aib-p-NA}

Peptide Boc-Leu-Aib-OH ${ }^{22 \mathrm{c}}(1.00 \mathrm{~g}, 3.16 \mathrm{mmol})$ was dissolved in $5 \mathrm{ml}$ of DMF. paraNitroaniline $(0.86 \mathrm{~g}, 6.32 \mathrm{mmol})$ was added to the former solution in ice-cold condition followed by addition of DCC $(0.98 \mathrm{~g}, 4.74 \mathrm{mmol})$ and HOBT $(0.43 \mathrm{~g}, 3.16 \mathrm{mmol})$. The reaction mixture was stirred at room temp for 2 days .The precipitated DCU was filtered off. The filtrate was 
diluted with ethylacetate. The organic layer was washed with $1 \mathrm{~N} \mathrm{HCl}(3 \times 30 \mathrm{ml})$ brine, $1 \mathrm{M}$ $\mathrm{Na}_{2} \mathrm{CO}_{3}$ solution $(3 \times 30 \mathrm{ml})$ and again with brine. The solvent was then dried over anhydrous $\mathrm{Na}_{2} \mathrm{SO}_{4}$ and evaporated in vacuo giving a light yellow gum. Yield: $1.2 \mathrm{~g}$ (86.95\%). The peptide was purified by column chromatography using 20\% ethylacetate-petroleum ether gradient. Single crystals were grown from acetone by slow evaporation and were stable at room temp. $\mathrm{Mp}=174^{0} \mathrm{C}$. Anal.Calcd for $\mathrm{C}_{21} \mathrm{H}_{32} \mathrm{~N}_{4} \mathrm{O}_{6}$ (436.50): C, 57.77; H, 7.38; N, 12.83. Found: C, 57.68; $\mathrm{H}, 7.31$; N, $12.73 \%$. $[\alpha]_{589}^{20}=-20^{0}$ (c=0.10 g per $\left.100 \mathrm{ml} ; \mathrm{CH}_{3} \mathrm{OH}\right)$; IR $(\mathrm{KBr}): 3754.1,3324.2$, 3259.6, 2953, 2868.3, 1674.3, 1602.9, 1524, $\mathrm{cm}^{-1} ;{ }^{1} \mathrm{H}$ NMR $300 \mathrm{MHz}\left(\mathrm{CDCl}_{3}, \delta \mathrm{ppm}\right): 9.50$ $(p \mathrm{NA}(3)-\mathrm{NH}, 1 \mathrm{H}, s), 8.17\left(\mathrm{H}_{\mathrm{a}} p \mathrm{NA}(3), 2 \mathrm{H}, d, J=5.1 \mathrm{~Hz}\right), 7.89\left(\mathrm{H}_{\mathrm{b}} p \mathrm{NA}(3), 2 \mathrm{H}, d, J=9 \mathrm{~Hz}\right)$, 6.36(Aib(2)-NH, 1H, s), 4.96( Leu(1)-NH,1H,s), 3.92( $\mathrm{C}^{\alpha} \mathrm{H}$ of $\left.\mathrm{Leu}(1), 1 \mathrm{H}, m\right), 1.57 \& 1.55\left(\mathrm{C}^{\beta} \mathrm{H}\right.$ of $\mathrm{Aib}(2), 6 \mathrm{H}, s), 1.25\left(\mathrm{C}^{\beta} \mathrm{H}\right.$ of $\left.\mathrm{Leu}(1), 2 \mathrm{H}, m\right), 1.46\left(\mathrm{Boc}_{-} \mathrm{CH}_{3} \mathrm{~s}, 9 \mathrm{H}, s\right), 0.97\left(\mathrm{C}^{\gamma}\right.$ and $\mathrm{C}^{\delta} \mathrm{H}$ of Leu(1), 7H, $m) .{ }^{13} \mathrm{C}$ NMR 75MHz $\left(\mathrm{CDCl}_{3}, \delta \mathrm{ppm}\right): 172.81,171.8,144.80,124.76,119.50,81.44$, 54.76, 40.12, 28.26, 26.10, 25.11, 24.90, 22.89, 21.76; HR-MS $\left(\mathrm{M}^{+} \mathrm{Na}^{+}\right)=459.16, \mathrm{M}_{\text {calcd }}$ $\left(\mathrm{M}^{+} \mathrm{Na}\right)^{+}=459.50$.

\section{Synthesis of the peptide 3a, Boc-Pro-Aib-OMe}

Boc-Pro-OH (2.0g, $9.30 \mathrm{mmol})$ was dissolved in a mixture of dichloromethane (DCM, $6 \mathrm{ml})$ and dimethylformamide (DMF, $2 \mathrm{ml}$ ). Aib-OMe obtained from its hydrochloride $(2.85 \mathrm{~g}, 18.6 \mathrm{mmol})$ was added to the former solution followed by addition of DCC $(2.87 \mathrm{~g}, 13.95 \mathrm{mmol})$ in ice-cold condition. The reaction mixture was stirred at room temp. for 1 day. The precipitated dicyclohexylurea (DCU) was filtered off. The filtrate was diluted with ethylacetate. The organic layer was washed with $1 \mathrm{~N} \mathrm{HCl}(3 \times 30 \mathrm{ml})$, brine, $1 \mathrm{M} \mathrm{Na}_{2} \mathrm{CO}_{3}$ solution $(3 \times 30 \mathrm{ml})$ and then again with brine. The solvent was dried over anhydrous $\mathrm{Na}_{2} \mathrm{SO}_{4}$ and evaporated in vacuo, giving a light yellow gum. Yield: $2.5 \mathrm{~g}(86 \%)$.

\section{Synthesis of the peptide $3 \mathrm{~b}$, Boc-Pro-Aib-OH}

Peptide 3a $(2.5 \mathrm{~g}, 7.96 \mathrm{mmol})$ was dissolved in methanol $(20 \mathrm{ml})$ and $2 \mathrm{~N} \mathrm{NaOH}(10 \mathrm{ml})$ was added to it. The reaction mixture was stirred for 1 day at room temperature. The progress of reaction was monitored by TLC. After completion of reaction the methanol was evaporated. The residue was diluted with water and washed with diethylether. The aqueous layer was cooled on ice, neutralized by using $2 \mathrm{~N} \mathrm{HCl}$ and extracted with ethylacetate. The solvent was evaporated in vacuo to give a waxy white coloured solid. Yield: $2.1 \mathrm{~g}(88 \%)$.

\section{Synthesis of the peptide 3, Boc-Pro-Aib-m-NA}

Peptide 3b (2.1g, $7.00 \mathrm{mmol})$ was dissolved in dichloromethane (DCM, 5ml). meta-Nitroaniline $(1.93 \mathrm{~g}, 14 \mathrm{mmol})$ was added to former solution, followed by addition of DCC (2.16g, 10.5 $\mathrm{mmol}$ ) in ice-cold condition. The reaction mixture was stirred at room temp for 2 days. The precipitated dicylohexylurea (DCU) was filtered off. The filtrate was diluted with ethylacetate. The organic layer was washed with $1 \mathrm{~N} \mathrm{HCl}(3 \times 30 \mathrm{ml})$, brine, $1 \mathrm{M} \mathrm{Na}_{2} \mathrm{CO}_{3}$ solution $(3 \times 30 \mathrm{ml})$ and then again with brine. The solvent was then dried over anhydrous $\mathrm{Na}_{2} \mathrm{SO}_{4}$ and evaporated in vacuo, to give a white solid compound. Purification was done using silica gel as stationary phase 
and ethylacetate-petroleum ether mixture (1:4) as eluent. Single crystals were grown from acetone by slow evaporation and were stable at room temp. Yield: $3.0 \mathrm{~g}$ (76.92\%). $\mathrm{Mp}=122^{0} \mathrm{C}$; Anal.Calcd for $\mathrm{C}_{20} \mathrm{H}_{28} \mathrm{~N}_{4} \mathrm{O}_{6}$ (420.34): C, 57.14; H, 6.68; N, 13.33\%; Found: C, 57.05; H, 6.59; N, 13.25\%. $[\alpha]_{589}^{20}=-18^{0}\left(\mathrm{c}=0.10 \mathrm{~g}\right.$ per $\left.100 \mathrm{ml} ; \mathrm{CH}_{3} \mathrm{OH}\right)$; IR $(\mathrm{KBr})$ : 3754.2, 3689.7, 3315.9, 2979.6, 2934.7, 1670.6, $1534.3 \mathrm{~cm}^{-1} ;{ }^{1} \mathrm{H}$ NMR $300 \mathrm{MHz}\left(\mathrm{CDCl}_{3}, \delta \mathrm{ppm}\right)$ : 9.51(mNA(3)-NH, $1 \mathrm{H}$, $s), 8.57\left(\mathrm{H}_{\mathrm{a}} m \mathrm{NA}(3), 1 \mathrm{H}, s\right), 8.21\left(\mathrm{H}_{\mathrm{d}} m \mathrm{Na}(3), 1 \mathrm{H}, d, J=7.2 \mathrm{~Hz}\right), 7.90\left(\mathrm{H}_{\mathrm{b}} m \mathrm{ABA}(3), 1 \mathrm{H}, d\right.$, $J=6 \mathrm{~Hz}), 7.43\left(\mathrm{H}_{\mathrm{c}} m \mathrm{NA}(3), 1 \mathrm{H}, t, J=8.1 \mathrm{~Hz}\right), 6.50(\mathrm{Aib}(2)-\mathrm{NH}, 1 \mathrm{H}, s), 4.15\left(\mathrm{C}^{\alpha} \mathrm{H}\right.$ of $\left.\operatorname{Pro}(1), 1 \mathrm{H}, m\right)$, 3.50( $\mathrm{C}^{\gamma} \mathrm{H}$ of $\left.\operatorname{Pro}(1), 2 \mathrm{H}, m\right), 2.23\left(\mathrm{C}^{\beta} \mathrm{H}\right.$ of $\left.\operatorname{Pro}(1), 2 \mathrm{H}, m\right), 1.98\left(\mathrm{C}^{\delta} \mathrm{H}\right.$ of $\left.\operatorname{Pro}(1), 2 \mathrm{H}, m\right), 1.46$ (Boc$\mathrm{CH}_{3}$ s, 9H, s), $1.64 \& 1.57\left(\mathrm{C}^{\beta} \mathrm{H}\right.$ of $\left.\mathrm{Aib}(2), 6 \mathrm{H}, s\right) ;{ }^{13} \mathrm{C} \mathrm{NMR} 75 \mathrm{MHz}\left(\mathrm{CDCl}_{3}, \delta\right.$ ppm):156.2,148.44, 140.05, 129.35, 125.83, 118.21,115.01, 81.37, 61.48, 57.90, 51.99, 47.41, 30.84, 29.64, 28.28, 26.53, 24.99, 24.62; HR-MS $\left(\mathrm{M}^{+} \mathrm{Na}^{+}\right)=443.20, \mathrm{M}_{\text {calcd }}\left(\mathrm{M}^{+} \mathrm{Na}\right)^{+}=443.34$.

\section{FT-IR spectroscopy}

IR spectra were examined using a Perkin Elmer-782 model spectrophotometer. The solid- state FT-IR measurements were performed using the $\mathrm{KBr}$ disk technique.

\section{NMR experiments}

All ${ }^{1} \mathrm{H}$ NMR and ${ }^{13} \mathrm{C}$ NMR spectra of peptides 1-3 were recorded on a Bruker Avance 300 model spectrometer operating at $300,75 \mathrm{MHz}$ respectively. The peptide concentrations were 10 $\mathrm{mM}$ in $\mathrm{CDCl}_{3}$ for ${ }^{1} \mathrm{H} \mathrm{NMR}$ and $40 \mathrm{mM}$ in $\mathrm{CDCl}_{3}$ for ${ }^{13} \mathrm{C} \mathrm{NMR}$. Solvent titration experiments were carried out at a concentration of $10 \mathrm{mM}$ in $\mathrm{CDCl}_{3}$ with gradual addition of $\mathrm{d}_{6}$-DMSO from $0-10 \% \mathrm{v} / \mathrm{v}$ approximately.

\section{Circular Dichroism spectroscopy}

Solutions of peptides 1-3 in $\mathrm{MeOH}$ (1.5 $\mathrm{mM}$ as final concentration) were used for obtaining the spectra. Far-UV CD measurements were recorded at $25^{\circ} \mathrm{C}$ with a $0.5 \mathrm{sec}$ averaging time, a scan speed of $50 \mathrm{~nm} / \mathrm{min}$, using a JASCO spectropolarimeter $(J 720$ model) equipped with a $0.1 \mathrm{~cm}$ pathlength cuvette. The measurements were taken at $0.2 \mathrm{~nm}$ wavelength intervals, $2.0 \mathrm{~nm}$ spectral bandwidth and five sequential scans were recorded for each sample.

\section{Field Emission scanning electron microscopic study}

The morphology of peptides 1-3 was investigated using field emission scanning electron microscope (FE-SEM). For the study, fibrous materials of peptide $\mathbf{1}$ were slowly grown from ethylacetate-petroleum ether and of peptide $\mathbf{2}$ and $\mathbf{3}$ were slowly grown from acetone and then dried and gold coated. The micrographs were taken using a FE-SEM apparatus (JEOL JSM 6700F).

\section{Mass spectrometry}

Mass spectra of peptides 1-3 were recorded on HEWLETT PACKARD Series 1100MSD and Micromass Qtof Micro YA263 Mass spectrometers by positive mode electro spray ionization. 
Table 3. Crystallographic refinement details for peptides 1-3

\begin{tabular}{llll}
\hline & Peptide 1 & Peptide 2 & Peptide 3 \\
\hline Crystal Colour & Colourless & Colourless & Colourless \\
Chemical Formula & $\mathrm{C}_{24} \mathrm{H}_{37} \mathrm{~N}_{3} \mathrm{O}_{6}$, & & \\
& $0.25 \mathrm{H}_{2} \mathrm{O}$ & $\mathrm{C}_{21} \mathrm{H}_{32} \mathrm{~N}_{4} \mathrm{O}_{6}$ & $\mathrm{C}_{20} \mathrm{H}_{25} \mathrm{~N}_{4} \mathrm{O}_{6}$ \\
Crystallising solvent & $\begin{array}{l}\text { Ethylacetate } \\
\text { Petroleum ether }\end{array}$ & Acetone & Acetone \\
Formula Weight $(\mathrm{g})$ & 469.08 & 436.51 & 417.44 \\
Crystal System & monoclinic & orthorhombic & orthorhombic \\
Space group & $\mathrm{P} 2_{1}$ & Pbcn & $\mathrm{P} 2{ }_{1} 2{ }_{1} 2$ \\
$\mathrm{Z}$ & 4 & 8 & 4 \\
$\mathrm{a}(\AA)$ & $13.6336(6)$ & $19.1499(15)$ & $28.9256(13)$ \\
$\mathrm{b}(\AA)$ & $10.8373(4)$ & $10.8592(8)$ & $13.1584(5)$ \\
$\mathrm{c}(\AA)$ & $18.4668(7)$ & $23.396(2)$ & $5.7929(2)$ \\
$\beta\left({ }^{\circ}\right)$ & $107.361(4)$ & $(90)$ & $(90)$ \\
$\mathrm{V}\left(\AA^{3}\right)$ & $2604.19(18)$ & $4865.2(7)$ & $2204.86(15)$ \\
Temperature $(\mathrm{K})$ & $150(2)$ & $150(2)$ & $150(2)$ \\
Unique reflections & 12531 & 7088 & 6422 \\
$\mathrm{~N}{ }^{\mathrm{o}}$ Parameters & 620 & 287 & 276 \\
$\mathrm{GoF}$ & 1.079 & 1.093 & 0.926 \\
$\mathrm{R}_{1}[\mathrm{I}>2 \sigma(\mathrm{I})]$ & 0.0518 & 0.0756 & 0.0554 \\
$w \mathrm{R}_{2}[\mathrm{I}>2 \sigma(\mathrm{I})]$ & 0.1137 & 0.2382 & 0.1203 \\
\hline & & &
\end{tabular}

Single crystal X-ray diffraction study

Crystal data and refinement details are given in Table 3. Diffraction data for the three peptides 1, 2 and 3, were obtained with MoKa radiation at 150K using the Oxford Diffraction X-Calibur CCD System. The crystals were positioned at $50 \mathrm{~mm}$ from the CCD. 321 frames were measured with a counting time of $10 \mathrm{~s}$. Data analyses were carried out with the Crysalis program. ${ }^{31}$ The structures were solved using direct methods with the Shelxs97 program. ${ }^{32}$ The non-hydrogen atoms were refined with anisotropic thermal parameters. The hydrogen atoms bonded to carbon and nitrogen were included in geometric positions and given thermal parameters equivalent to 1.2 times (1.5 times for methyl hydrogens) those of the atom to which they were attached. Crystallographic details have been deposited at the Cambridge Crystallographic Data centre, reference CCDC 734094 - 734096 inclusive. 


\section{Acknowledgements}

S.K. thanks CSIR, New Delhi, India, for a Senior Research Fellowship (SRF). The financial assistance of UGC, New Delhi is acknowledged [Major Research Project, No.32-190/2006(SR)]. We acknowledge the financial assistance of Centre for Research in Nanoscience \& Nanotechnology, University of Calcutta. We thank EPSRC and the University of Reading, UK for funds for Oxford Diffraction X-Calibur CCD diffractometer.

\section{References and Notes}

1. Maji, S. K.; Banerjee, A.; Drew, M. G. B.; Halder, D.; Banerjee, A. Tetrahedron Lett. 2002, 43, 6759 .

2. Halder, D.; Maji, S. K.; Drew, M. G. B.; Banerjee, A. Tetrahedron Lett. 2002, 43, 5465.

3. Maji, S. K.; Drew, M. G. B.; Banerjee, A. Chem. Commun. 2001, 1946-1947.

4. Vauthey, S.; Santoso, S.; Gong, H.; Watson, N.; Zhang, S. Proc. Natl. Acad. Sci. USA 2002, 99, 5355.

5. Rathore, O.; Sogah, D. Y. J. Am. Chem. Soc. 2001, 123, 5231.

6. Caplan, M. R.; Moore, P. N.; Zhang, S.; Kamm, R. D.; Lauffenburger, D. A. Biomacromolecules 2000, 1, 627.

7. Krejchi, M. T.; Atkins, E. D. T.; Waddon, A. J.; Fournier, M. J.; Mason, T. L.; Tirrel, D. A. Science 1994, 265, 1427.

8. Wang, W.; Hecht, M. H. Proc. Natl. Acad. Sci. USA 2002, 99, 2760.

9. Antzutkin, O. N.; Balbach, J. J.; Leapman, R. D.; Rizzo, N. W.; Reed, J.; Tycko, R. Proc. Natl. Acad. Sci. USA 2000, 97, 13045.

10. Tjernberg, L. O.; Callway, D. J. E.; Tjernberg, A.; Hahne, S.; Lilliehöök, C.; Terenius, L.; Thyberg, J.; Nordsted, C. J. Biol. Chem. 1999, 274, 12619.

11. Benzinger, T. L. S.; Gregory, D. M.; Burkoth, T. S.; Miller-Auer, H.; Lynn, D. G.; Botto, R. E.; Maredith, S. C. Proc. Natl. Acad. Sci. USA 1998, 95, 13407.

12. Dutt, A.; Drew, M. G. B.; Pramanik, A. Org. Biomol. Chem. 2005, 3, 2250.

13. Kundu, S. K.; Majumder, P. A.; Das, A. K.; Bertolasi, V.; Pramanik, A. J. Chem. Soc. Perkin Trans. 2002, 2, 1602.

14. Maji, S. K.; Haldar, D.; Drew, M. G. B.; Banerjee, A.; Das, A. K.; Banerjee, A. Tetrahedron 2004, 60, 3251.

15. Banerjee, A.; Maji, S. K.; Drew, M. G. B.; Haldar, D.; Banerjee, A. Tetrahedron Lett. 2003, 44, 335.

16. Halder, D.; Maji, S. K.; Sheldrick, W. S.; Banerjee, A. Tetrahedron Lett. 2002, 43, 2653.

17. Kar, S.; Dutta, A.; Drew M. G. B.; Koley, P. Pramanik, A. Supramolecular Chemistry DOI: 10.1080/10610270802709378. 
18. Lashuel, H. A.; LaBrenz, S. R; Woo, L; Serpell, L. C.; Kelly, J. W. J. Am. Chem. Soc. 2000, $122,5262$.

19. (a) Venkatraman, J.; Shankaramma, S. C.; Balaram, P. Chem Rev. 2001, 101, 3131. (b) Andreeto, E.; Peggion, C.; Crisma, M.; Toniolo, C. Biopolymers 2006, 84, 490. (c) Rai, R.; Aravinda. S.; Kanagarajadurai, K.; Raghothama, S.; Shamala, N.; Balaram, P. J. Am. Chem. Soc. 2006, 128, 7916. (d) Crisma, M.; Andreeto, E.; Zotti, M. D.; Moretto, A.; Peggion, C.; Formaggio, F.; Toniolo, C. J. Pept. Sci. 2007, 13, 190.

20. Maji, S. K.; Malik, S.; Drew, M. G. B.; Nandi, A. K.; Banerjee, A. Tetrahedron Lett. 2003, 44, 4103.

21. Maji, S. K.; Drew, M. G. B.; Banerjee, A. Chem. Commun. 2001, 1946.

22. (a) Dutt, A.; Dutta, A.; Mondal, R.; Spencer, E. C.; Howard, J. A. K.; Pramanik, A. Tetrahedron 2007, 63, 10282. (b) Halder, D.; Drew, M. G. B.; Banerjee, A. Tetrahedron 2007, 63, 5561. (c) Dutt, A.; Drew, M. G. B.; Pramanik, A. Tetrahedron 2005, 61, 11163. (d) Das, A. K.; Banerjee, A.; Drew, M. G. B.; Ray, S.; Haldar, D.; Banerjee, A. Tetrahedron 2005, 61, 5027. (e) Dutt, A.; Frohlick, R.; Pramanik, A.; Org. Biomol. Chem. 2005, 3, 661. (f) Banerjee, A.; Maji, S. K.; Drew, M. G. B.; Haldar, D.; Banerjee, A. Tetrahedron Lett. 2003, 44, 6741.

23. Lee, H. B.; Zaccaro, M. C.; Pattarawarapan, M.; Roy, S.; Saragovi, H. B.; Burgess, K. J. Org. Chem. 2004, 69, 701.

24. Venkatachalam, C. M. Biopolymers 1968, 6, 1425.

25. (a) Dutt, A.; Drew, M. G. B.; Pramanik, A. Tetrahedron, 2005, 61, 11163. (b) Crisma, M.; Valle, G.; Toniolo, C.; Prasad, S.; Rao, R. B.; Balaram, P.; Biopolymers 1995, 35, 1.

26. (a) Banerjee, A.; Raghothama, S.; Balaram, P. J. Chem. Soc. Perkin Trans. 1997, 2, 2087.

(b) Karle, I. L.; Banerjee, A.; Bhattacharya, S.; Balaram, P. Biopolymers 1996, 38, 515.

27. Prasad, S.; Rao, R. B.; Balaram, P. Biopolymers 1994, 35, 11.

28. Lamm, M. S.; Rajagopal, K.; Schneider, J. P.; Pochan, D. J. J. Am. Chem. Soc. 2005, 127, 16692.

29. (a) Sone, E. D.; Stupp, S. I. J. Am. Chem. Soc. 2004, 126, 12756. (b) Meegan, J. E.; Aggeli, A.; Boden, N.; Brydson, R.; Brown, A. P.; Carrick, L.; Brough, A. R.; Hussain, A.; Ansell, R. J. Adv. Funct. Mater. 2004, 14, 31. (c) Mao, C.; Flynn, C. E.; Hayhurst, A.; Sweeney, R.; Qi, J.; Georgiou, G.; Iverson, B.; Belcher, A. M. Proc. Natl. Acad. Sci. U. S. A. 2003, 100, 6946. (d) Scheibel, T.; Parthasarathy, R.; Sawicki, G.; Lin, X. M.; Jaeger, H.; Lindquist, S. L. Proc. Natl. Acad. Sci. U. S. A. 2003, 100, 4527. (e) McMillan, R. A.; Paavola, C. D.; Howard, J.; Chan, S. L.; Zaluzec, N. J.; Trent, J. D. Nat. Mater. 2002, 1, 247. (f) Hartgerink, J. D.; Beniash, E.; Stupp, S. I. Science 2001, 294, 1684. (g) Shenton, W.; Douglas, T.; Young, M.; Stubbs, G.; Mann, S. Adv. Mater. 1999, 11, 253.

30. Gazit, E. J. FASEB 2002, 16, 77.

31. Crysalis, v1 (2005) Oxford Diffraction Ltd., Oxford, U.K.

32. G. M. Sheldrick, SHELXS-97 and SHELXL-97, Programs for Crystal Structure solution and determination, University of Göttingen: Göttingen, Germany, 1997. 